\author{
Paweł PIĄTKOWSKI, PhD \\ Faculty of Economics and Management, University of Bialystok \\ e-mail: p.piatkowski@uwb.edu.pl \\ ORCID: 0000-0003-0560-6290
}

DOI: $10.15290 /$ oes.2018.03.93.11

\title{
STOCK-FLOW ADJUSTMENT IN THE EVALUATION OF PUBLIC DEBT DYNAMICS IN POLAND
}

\begin{abstract}
Summary
Goal - The aim of the paper is to analyse the significance of the economic category referred to as stock-flow adjustment (SFA) for the evaluation of the level and dynamics of public debt in Poland. The category is an important part of the analyses called excessive deficit procedure (EDP) conducted by The European Commission. It is also a major contributor to the growth of public debt. It is also related to political activities which fall into the category of creative accounting. Stock-flow adjustment is, therefore, a threat to the stability of public debt. In spite of all this, SFA is not taken into account in Polish documents related to debt management.

Research methodology - The analysis performed by the Author is based on the desk research method. It is mostly a qualitative analysis, relying on the literature and both strategic and operational documents of the European Commission and the Polish Ministry of Finance.

Stock-flow adjustment is widely regarded in literature as an expression of the hidden part of public debt dynamics. This paper offers an evaluation of SFA's influence on public debt and its different degrees across both developing and developed countries. Moreover, the documents of the European Commission and the Polish Ministry of Finances are analysed from the point of view of SFA.

Score - The analysis undertaken in the paper reveals that stock-flow adjustment has a strong impact on the occurrence of the so-called debt pikes, i.e. sharp increases in public debt. Many authors' conclusions confirm that SFA considerably affects the level of debt. They also associate it with the restrictiveness of fiscal rules and creative accounting. Thus, SFA is an important element of public debt sustainability. SFA is included in European Commission analyses, but fails to be recognized by Polish documents. It is strongly recommended that SFA is taken into consideration in public debt management in Poland.
\end{abstract}

Key words: public debt, stock-flow adjustment, public finances

JEL classification: H62, H63

\section{Introduction}

Presently public debt management, including the control of its dynamics, constitutes an essential element of economic policy. Substantial debt levels occurring in most countries contribute to the fact that each year it is necessary to obtain adequate funds to finance it. Owing to the regular occurrence of budget deficits it is necessary to obtain funds for financing them on a regular basis as well as for keeping current 
liquidity of entities in the public finance sector. At the same time as the debt is increasing, there are implemented considerably more restrictive regulations reducing budget imbalance and public debt, such as fiscal rules. In the light of this contradiction there arises (and even increases) the temptation to undertake non-budget activities or activities related to creative accounting. They are not illegal, but they have frequently serious consequences for the value of public debt. Owing to the security of public finance it is necessary to control such activities in the most careful way (although it is impossible to control them fully). The aim of the paper is to present the role of the category referred to as stock-flow adjustment in the process of controlling the dynamics of public debt in terms of the elements not included in the budget deficit. The category is monitored and used by the European Commission and at the same time it is virtually absent in public debt management in Poland.

\section{The concept and structure of stock-flow adjustment}

Public debt is the value of resource type that expresses the nominal sum of unpaid liabilities of the public sector. It aggregates various liabilities of the entities included into the public finance sector. Its value is calculated for a particular moment because it changes over time. Its primary source is the financing of budget deficits understood as the difference between incomes and expenditure of the budget in a certain time period. Therefore, deficit is the stream of loan requirements that generates debt, i.e. the resource of the commitments made in this way [Samuelson, Nordhaus, 2000, p. 431; Wernik, 2011]. In accordance with the aforementioned dependence, public debt in year $\mathrm{t}$ is dependent on the value of debt in year t-1 and on the value of the budget deficit in year $t$, which is presented as follows [Maltritz, Würste, 2015, p. 226]:

$$
\mathrm{B}_{\mathrm{t}}=\mathrm{B}_{\mathrm{t}-1}+\mathrm{D}_{\mathrm{t}}
$$

where:

$\mathrm{B}_{\mathrm{t}}, \mathrm{B}_{\mathrm{t}-1}-$ public debt in $\mathrm{t}$ and $\mathrm{t}-1$ periods, $\mathrm{D}_{\mathrm{t}}$-budget deficit.

In such situation the increase of debt in year $\mathrm{t}$ would be identical with the budget deficit in year $t\left(\Delta \mathrm{B}_{\mathrm{t}}=\mathrm{D}_{\mathrm{t}}\right.$. . However, the observations made by $\mathrm{J}$. von Hagen and G.B. Wolf show that for the last 30 years of their analysis the difference (both as the advantage and disadvantage) between the increase of debt and deficit $\mathrm{m}$ is huge $\left(\Delta \mathrm{B}_{\mathrm{t}} \neq \mathrm{D}_{\mathrm{t}}\right)$ [Hagen, Wolf, 2004, 2006]. During the search for the sources of these divergences one may indicate that the level of debt is influenced not only by the nominal value of the liabilities made. Additionally, one needs to take into consideration the changes occurring as the result of the overestimation of the value of foreign debt. Changes in the exchange rates are of special importance in those countries where the share of nominated bonds in foreign currencies is significant. Another factor that increases the value of debt are the costs related to the roll-over of com- 
mitments, e.g. resulting from the sale of bonds with discount or the capitalization of interest [Chojna-Duch, 2007, p. 166]. The crisis connected with Greek debt showed how essential are the hidden components of debt that result from the so-called creative accounting and shifting of expenditure to the entities not included in the public finance sector. The conducted research concerning the impact of creative accounting on public debt shows that the larger is the number of fiscal rules and other restrictions in terms of the value of the budget deficit exist, the greater is the willingness of politicians to initiate activities related to creative accounting [Reischmann, 2016; Maltritz, Würste, 2015].

The illustration of the differences mentioned above was useful for forming definitions of the economic category referred to as stock-flow adjustment (SFA) ${ }^{1}$. This value may be presented in the following way [Maltritz, Würste, 2015, p. 226]:

$$
\mathrm{SFA}=\mathrm{B}_{\mathrm{t}}-\mathrm{B}_{\mathrm{t}-1}-\mathrm{D}_{\mathrm{t}}
$$

where:

$\mathrm{Bt}, \mathrm{Bt}-1$ - public debt in $\mathrm{t}$ and $\mathrm{t}-1$ periods respectively, Dt -budget deficit.

Stock-flow adjustment denotes the difference between change in the level of public debt and the level of budget deficit / budget surplus of the public finance sector [Stock-flow adjustment (SFA) for the Member States..., 2017, p. 1]. In literature there is an expression that means "hidden" deficit/surplus of the public finance sector. This category comprises changes having various reasons, excluding budget deficit. Such general expression of this category enables taking into consideration various aspects of the inconsistencies between the increase of debt and the achieved budget deficit. It is a vital characteristic of this concept because politicians have more and more ways of omitting the restrictions and limitations in state debt.

The structure of SFA in accordance with the calculation methodology adopted by Eurostat is composed of the following elements [Stock-flow adjustment (SFA) for the Member States..., 2017, p. 3]:

1. net acquisition of financial assets:

a) currency and deposits,

b) debt securities,

c) loans (short-term and long-term ones),

d) equity and investment fund (shares/units) (portfolio investments, net + equity and shares/participation units in funds + investment funds other than portfolio investments),

e) financial derivatives,

f) other accounts receivable,

g) other financial assets,

1 Presently there is no Polish term that fully expresses the meaning of English concept stock-flow adjustment. There is a Polish term „zmiana rezydualnej wartości długu publicznego” (eng. The shift of the residual value of public debt), but it is used particularly seldom. 
2. adjustments:

a) net incurrence of liabilities in financial derivatives,

b) net incurrence of other accounts payable,

c) net incurrence of other liabilities,

d) issuances above/below nominal value,

e) difference between interest accrued and paid,

f) redemptions/repurchase of debt above/below nominal value,

g) appreciation/depreciation of debt denominated in foreign currency debt,

h) changes in sector classifications,

i) other volume changes in financial liabilities,

3. statistical discrepancies.

The analysis of the aforementioned structure shows that stock-flow adjustment is generated by two basic groups of factors: the net acquisition of financial assets and adjustments. Financial operations are connected with the wealth accumulated by public finance sector in the form of stock or participation units. Increase in terms of the possessed funds is connected chiefly with the establishment or the capitalization of state-owned companies. They become responsible for the realization of certain public tasks or they have the obligation to enter into commitments. The value of the capital involved in these operations is not included by governments into deficit. Since it causes increase in debt numerous times the information is not directly made public, among others, for Parliament members. This category regards also operations regarding securities that are connected with purchase for a higher price than the nominal debt or with the issue of securities with discount, owing to which the debt increases to a larger degree than it results from the deficit. However, not all the elements depend on the conscious decisions of politicians. The category of adjustments results, to a large extent, from factors that are difficult to predict or are random, such as changes of the exchange rate. They cause change in the value of debt calculated in the national currency and it is difficult to predict. Their impact on debt depends on the debt structure and on the instruments that are used to finance it. The larger is the share of debt denominated in foreign currencies, the greater is sensitivity to changes of the exchange rates. On the other hand, the higher is the share of instruments having variable interest rate, the larger is sensitivity to the changes of interest rates. The classification of elements includes also such concept as statistical discrepancies. It results from the fact that governments frequently use their own ways of classifying debt titles included into public debt and institutions that enter into commitments in the public finance sector.

One may observe that each of these categories included in SFA (apart from their basic components) include also the position "other". It results from the fact that it is impossible to predict all the factors having impact on change in the value of public debt. Owing to this an essential characteristic of SFA is the multitude of definitions.

Stock-flow adjustment may adopt the following values [Rybacek, 2015, p. 8]:

- $\quad$ SFA $=0-$ which means that the change of debt directly corresponds to the budget deficit, 
- $\quad$ SFA $>0$ - which means increase in the debt level above the deficit level,

- $\quad$ SFA $<0$ - which means that debt increased more than the deficit would contribute to).

The interpretation of the sign of this category is not unambiguous. While the positive value of SFA is always connected with the increase of debt, it may result from temporary factors such as the changes of exchange rates. Similarly, negative SFA ought to be a positive element of public debt management. However, it may be either temporary or result from gaining fortune or remitting bonds (e.g. the acquisition of pension funds from fully funded pillars). Therefore, the analysis of SFA value must be supplemented with the analysis of its structure and the sources of changes.

The aforementioned definitions do not convey fully the complexity of this concept. The analysis of the practical aspects of SFA assessment enables the isolation of several crucial aspects.

Firstly, the category defined in such manner comprises changes resulting from the reasons not included in the sum of the budget deficit. It indicates elements that are not included in public statistics but become visible solely owing to their impact on the value of public debt. They are included chiefly in the items "other" in the classification of components. Owing to this it is not subject to such careful supervision of Parliament members as it is the case with the budget deficit because it is not so transparent and understandable. Therefore, it is important to monitor SFA even if the assessments are presented ex-post. Then, at least, it is possible to draw conclusions for the future.

Secondly, SFA is the category of a result type, not the accrual category - it is a real difference resulting from the spot values that were actually recorded. That is the reason why it is difficult to assess ex-ante the value of SFA. The prediction of its elements is difficult. It result from the fact that some of them depend on factors that are hard to predict, e.g. the changes of exchange rates. Overestimations being the results of them are an essential element although they frequently have impact on debt in various ways - by either increasing or decreasing it.

Thirdly, politicians are not always interested in a precise disclosure of some elements of SFA. Some of these elements result from the so-called creative accounting, i.e. from the actual deficit in order to conform with the norms specified by law. In such situation the analysis of the values of SFA is particularly essential because it enables figuring out what is the scale of fraud.

Consequently, SFA constitutes a useful element of public debt management that enables more efficient monitoring of the real situation in terms of the dynamics of public debt. 


\section{The dynamics of public debt in the European Union}

By establishing the Economic and Monetary Union, countries of the European Union in the Maastricht Treaty specified what is the maximum accessible public debt level (60\% GDP) and budget deficit: (3\% GDP). Apart from the conditions included in the treaty, this solution was supposed to ensure the security of fiscal policies realized by countries from the euro area. In case of monetary policy there was selected full coordination, but it was not the case as regards the fiscal policy. There was no realization that it may have negative consequences. The mechanisms from the Maastricht Treaty aimed at ensuring fiscal stability of the monetary union. Unfortunately, since the introduction of euro the mechanisms of enforcing the application of fiscal rules have been inefficient. They have not been improved for a number of years. Only after substantial increase in the level of public debt and budget deficit in the times of economic crisis in the years 2008-2010 there were introduced mechanisms preventing economy from excessive fiscal and economic imbalance.

The undertaken activities were in two directions: there were created financial instruments offering aid for countries facing crisis, and later on there were passed regulations reinforcing the coordination of fiscal policy and implementing the mechanisms for coordination of economic policy in order to prevent the occurrence of similar crises in the future. The European Financial Stabilisation Mechanism and the European Financial Stability Facility (which were formed at first) had temporary character and offered only temporary aid. Further on there was established European Stability Mechanism (ESM), which in principle was supposed to be the target instrument. It had the status of international financial institution having funds worth $€ 700$ bln allocated for short-term aid for countries from the euro area that have temporary difficulties. Unfortunately, the prudential and preventive function of this instrument has not been performed because the initial restrictive requirements regarding the obtainment of aid were considerably mitigated [Trzcińska, 2013].

The solutions that were supposed to prevent debt crisis in the future included new EU regulations. The first solutions included the so-called Six-Pack, i.e. the set of 5 regulations and 1 directive [The Regulation of the European Parliament and of the Council (EU) no. 1175/2011..., 2011; The Regulation of the European Parliament and of the Council no. 1173/2011..., 2011; The Regulation of the European Parliament and of the Council (EU) no. 1177/2011..., 2011; The Regulation of the European Parliament and of the Council (EU) no. 1176/2011..., 2011; The Regulation of the European Parliament and of the Council (EU) no. 1174/2011..., 2011; The Council Directive 2011/85/EU..., 2011]. They aimed at:

- enforcing efficient budget supervision in euro area,

- improving the procedure of excessive deficit,

- reinforcing the coordination of economic policies,

- creating budget frameworks of member states,

- avoiding disturbances of macroeconomic equilibrium and correcting them,

- creating the mechanism of correcting excessive disturbances of macroeconomic equilibrium in euro area [Trzcińska, 2013]. 
Additionally, there was introduced the so-called European semester (the procedure lasting approx. six months). During the semester the European Commission monitors the economic situation in EU states, and then formulates both the objectives and recommendations for particular countries that aim at preserving the stability of economies, improved economic situation and reinforcement of convergence. There recommendations are discussed within the Union and are adopted after successive rounds. Then the EU states have the next six months to implement them in their budgets for the subsequent years [Trzcińska, 2013].

The last package of recommendations was the so-called Two-Pack, i.e. regulations ${ }^{2}$ aiming at:

- $\quad$ reinforcing economic and budget supervision of member states belonging to the euro area that are either affected or threatened by serious difficulties with reference to their financial stability

- monitoring and assessing drafts of budget plans as well as ensuring the correction of excessive deficit in member states belonging to the euro area [Trzcińska, 2013].

A particularly essential solution aiming at ensuring better balance of budgets in the public finance sector units (especially central budgets) and complying with the limitations as regards EU member states getting into debt was the so-called excessive deficit procedure (EDP). This procedure was mentioned in article 126 of the Treaty on the functioning of the European Union. Within the Stability and Growth Pact it constituted the recovery element. It provided for the undertaking of actions when the country did not meet the requirements of the Maastricht Treaty in terms of the budget deficit and public debt unless the deficit decreased constantly or substantially or when the exceeding of deficit had a short-term character, and the deficit level was close to the reference level [Traktat o funk.jonowaniu Unii Europejskiej..., art. 126]. Within EDP countries submit a report (art. 126 item 3). As provided by the articile, the countries preparing the report present not only the value of deficit and debt, but also information concerning public investments and other factors having influence on the mid-term budget situation of the country. The information includes also the control of stock-flow adjustment as the factor having considerable impact on the debt level. Table 1 presents stock-flow adjustment from the perspective of the procedure of excessive deficit.

The European Commission indicates that the essential elements having impact on the assessment of the fiscal situation are the operations connected with the management of budget liquidity. The Commission indicates the resources of cash accumulated for financing the future deficits. In another situation such resources may be used for temporary reduction of the debt level so that it was possible to observe more advantageous debt levels. Such operations ought to be considered in the assessment of the fiscal situation of particular EU states. The Commission indicates

2 One needs to mention: [The Regulation (EU) of the European Parliament and of the Council no. 472/2013..., 2013; The Regulation (EU) of the European Parliament and of the Council no. 473/2013]. 
that such operations cause major differences amounting to as much as $+/-5 \%$ of GDP [European Commission, 2017, p. 80].

TABLE 1

The elements constituting change in the level of public debt in accordance with Eurostat data

\begin{tabular}{|c|l|ll|l|}
\hline \multicolumn{4}{|c|}{ Change in the debt level } \\
\hline deficit & \multicolumn{3}{|c|}{ Stock-flow adjusment (SFA) } & Statistical \\
\cline { 2 - 4 } & The net acquisition of financial & Adjustments: & discrepancies \\
& assets: & a) & Derivative instruments & \\
& a) & Money and deposits & b) & other adjustments \\
& b) Commercial papers & c) & Exchange rate effects & \\
& c) Loans & d) & Other changes in the value & \\
& d) Stock and shares & & of financial adjustments & \\
& e) Other financial assets & & & \\
\hline
\end{tabular}

Source: [European Commission, 2017, p. 79].

\section{Stock-flow adjustment versus the dynamics of debt in European Union countries}

The European Commission has assessed the value of SFA for a number of years. Therefore, the following question arises: In what way does this category contribute to the assessment of debt dynamics. Below there are conclusions from the assessment of SFA for the European Union countries. The analysis comprises the years 2005-2017. In this period the Union included at least 25 countries and the analysis includes the period preceding the economic crisis, the crisis itself and the years following the crisis. Therefore, it is possible to make a comprehensive evaluation of the SFA dynamics. All the data was taken from the reports Stock-flow adjustment (SFA) for the Member States, the euro area and the EU27 [2005-2018] prepared by Eurostat on the basis of data reported by member states within the procedure of excessive deficit.

In the first place the attempt was made to answer the question whether the value of SFA truly has impact on the change of public debt level. The average value of SFA in the years 2005-2017 amounted to 0,54\% GDP. In the same period the average budget deficit amounted to 2,8\% GDP. Thus, the average value of SFA is not particularly high in comparison with the deficit value. However, one needs to observe that it is more than 1/6 of the deficit limit established in the Maastricht Treaty. Furthermore, SFA changes the sign more frequently than the budget balance. The average value is partly the effect of the compensation of positive values (that increase the public debt) and the negative ones (that reduce the debt). Owing to this the real values more frequently adopt values that are higher than average. Chart 1 presents The average, minimum and maximum value of SFA in the European Union. 
The average, minimum and maximum value of SFA in the European Union in the years 2005-2017

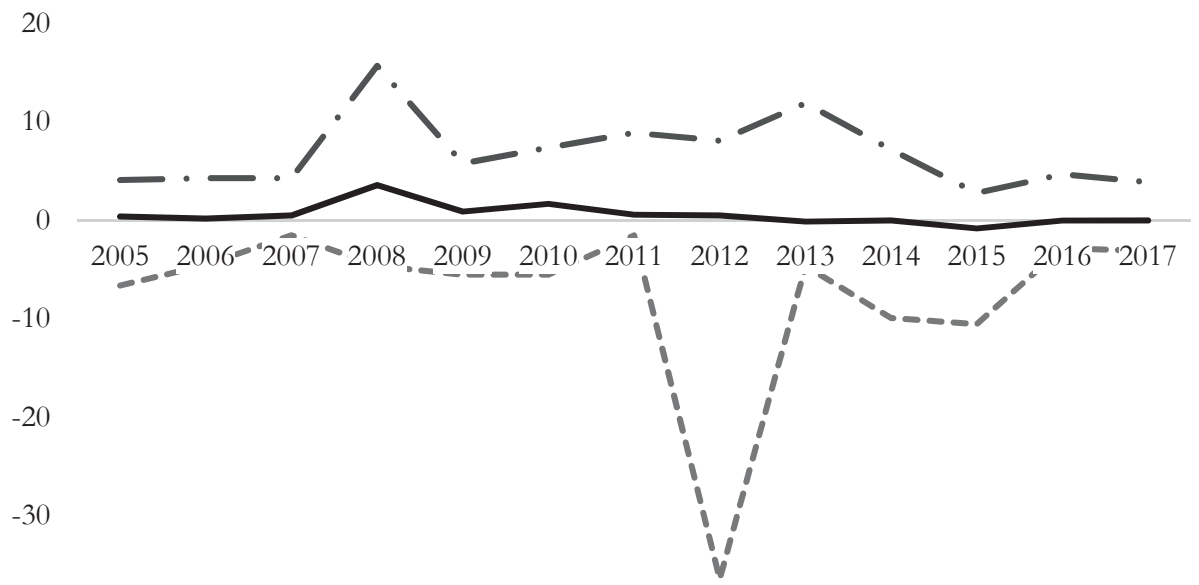

$-40$

-SFA - average $\quad---\mathrm{SFA}$ - minimum —. SFA - maxsimum

Source: own elaboration on the basis of data included in: [Stock-flow adjustment (SFA) for the Member States..., 2006-2018].

As one may observe, the minimum and maximum values in the analyzed period presented in chart 1 in particular years are significantly lower/higher than the average ones. The highest value of SFA amounted to 15,7\% GDP and was observed in 2008 in the Netherlands. The value is high and there are more such values because the values higher than 10\% GDP in the analyzed period occurred five times in five different countries (in four among these cases - in 2008). The values higher than 5\% GDP occurred as many as 20 times, whereas the values lower than 3\% GDP (i.e. the limitation from the treaty) occurred frequently. The negative values of SFA (which denote lower increase of debt than the increase resulting from the budget deficit) in the analyzed period were observed in less than 1/3 cases. However, these values are considerably lower than positive values. SFA below - 10\% GDP has occurred only twice in Greece and it was connected with the partial cancellation of Greek public debt. The values below - 5\% GDP occurred only 7 times (per 356 observations). In comparison, in case of deficits, the values above 10\% GDP occurred 13 times in the analyzed period. Particularly high values occurred in Ireland (which was caused by the saving of the bank sector) and Greece. There are considerably more cases when deficit was higher than 5\% GDP - there were 81 cases. Budget surpluses in the countries of the European Union were observed more seldom than the negative values of SFA. Only in approx. 1/7 observations (69) there was recorded positive balance of the public finance sector. The highest surplus was 5\% GDP in Denmark 
before the crisis. Thus SFA is much more changeable in terms of the sign and value than budget deficits. Owing to this SFA is a considerably less predictable economic category that may have strong impact on the value of public debt.

CHART 2

Accumulated value of SFA and budget deficit in the years 2005-2017 (in \% GDP)

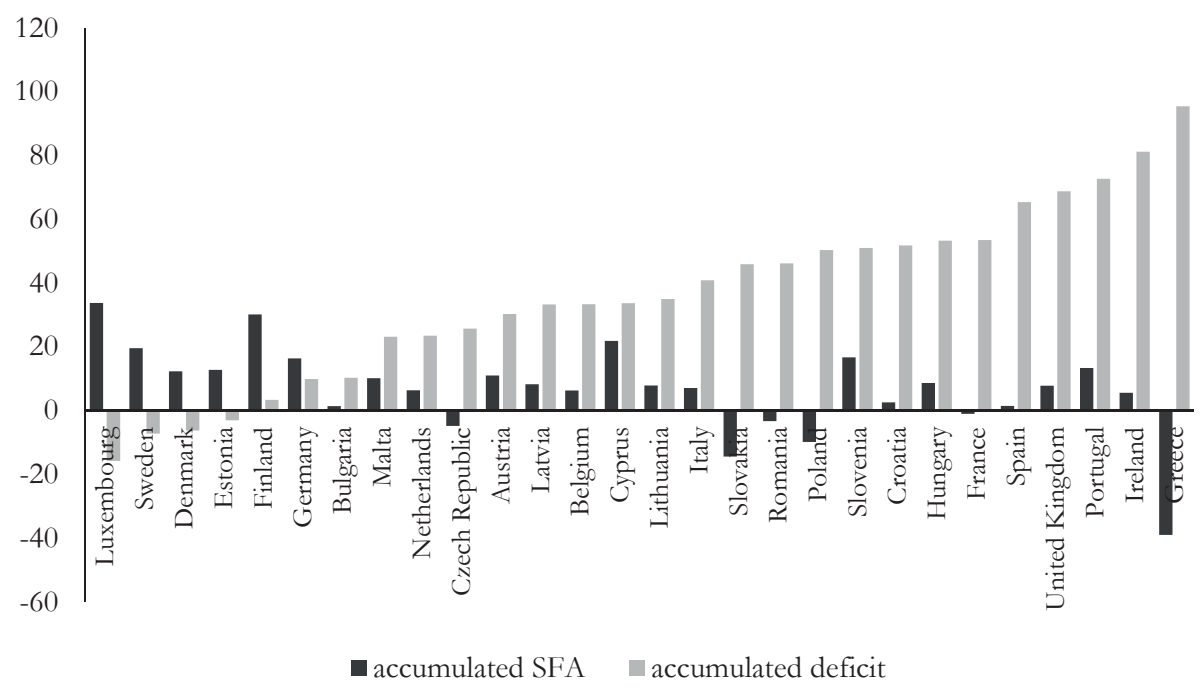

Sources: own elaboration on the basis of data included in: [Stock-flow adjustment (SFA) for the Member States..., 2006-2018].

The observation of accumulated values indicates that the highest accumulated SFA is in Luxembourg (33.9\% GDP), Finland (30.3\% GDP) and Cyprus (22\% GDP). These countries were characterized by having positive SFA much more frequently than the negative SFA. In the analyzed period the increase of debt related to it appears to be substantial. Among other countries eight have accumulated SFA oscillating from 10 to $20 \%$ GDP, in twelve other countries SFA oscillates from 0 to $10 \%$ GDP, whereas six other countries have negative value of the accumulated SFA, but it results partly from such operations as the cancellation of Greek debt or cancellation of some OFE funds in Poland. Even though these values are rather substantial in absolute terms, they are relatively low in comparison with the accumulated deficits. Only Denmark, Estonia, Luxembourg and Sweden have accumulated surplus in the analyzed period. Other countries have indicated accumulated deficit. In case of some countries the deficit is very high and reaches 95,6\% GDP in Greece, $81,3 \%$ in Ireland and almost 70\% GDP in Great Britain and Spain. In 16 other countries the accumulated deficits oscillated from 30 to 60\% GDP. Hence the accumulated SFA additionally worsens the situation that is already bad in terms ofthe balance of the public finance sector. 
CHART 3

The structure of SFA for the European Union in the years 2005-2017 (in \% GDP)

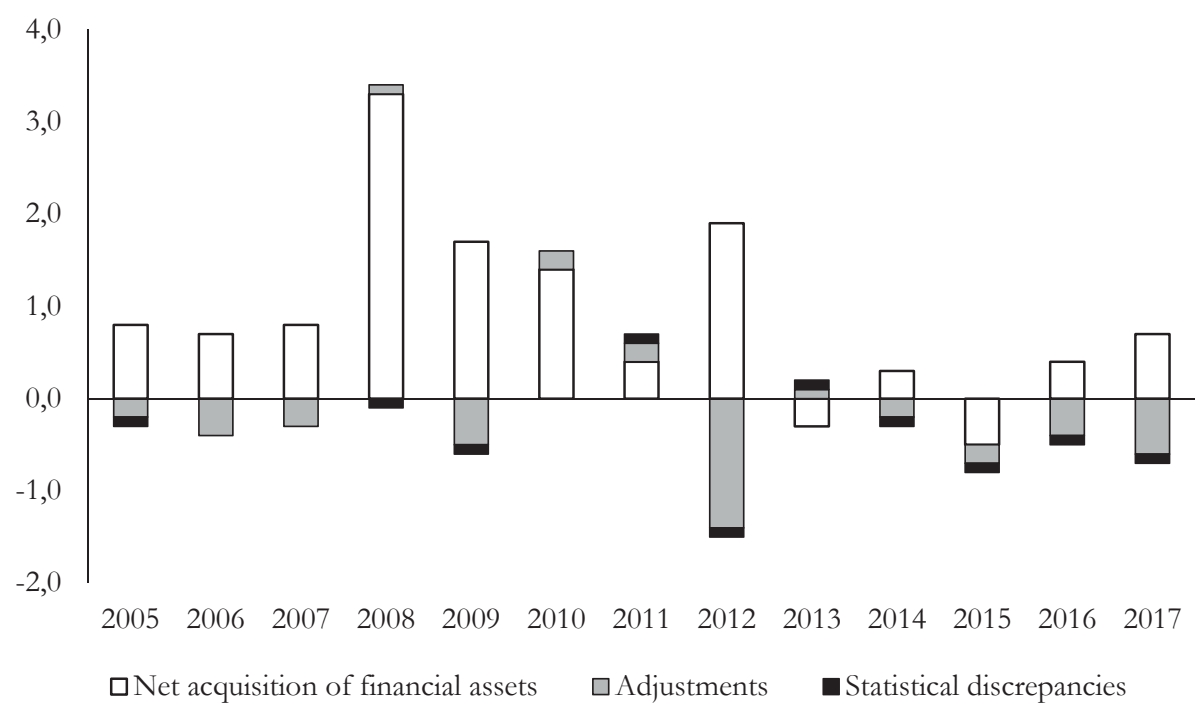

Source: own elaboration on the basis of data included in: [Stock-flow adjustment (SFA) for the Member States..., 2006-2018].

Another essential issue is the structure of SFA for the European Union. It was presented on chart 3. One may observe that each of three presented categories (the net acquisition of assets, adjustments, statistical discrepancies) is changeable. The net acquisition of assets for the entire period (with the exception of 2013 and 2015) was positive, thus it increased the level of public debt. However, the scale of this impact was very changeable. In the initial period it remained at rather stable level, while in 2008 it increased almost four times. In the subsequent two years it decreased by one half, but it still remained at high level. In 2011 this impact decreased, while in 2012 it exceeded $€ 200$ bln once again. In the subsequent years it was much lower and very changeable, however since 2015 one may observe clearly the increasing tendency. The impact of the second category (adjustments) was much smaller. For the major part of the analyzed period this category has adopted negative values. The years: 2008, 2010, 2012 and 2014 were the exception. In most years the category adopted rather low values, but in 2012 it reached the level of $€ 186 \mathrm{bln}$, while in 2017 - €87 bln. The least important category were statistical discrepancies. They constituted solely insignificant part of SFA. The value of this category oscillated from - €18 bln to €7,1 bln. Within nine years it adopted negative values, while in four others the value was positive. Hence the value was rather changeable. Therefore, the analysis of SFA structure indicates that the impact of particular categories on SFA is diverse and also changeable (frequently it may be even contradictory). 
The operations connected with securities have achieved the strongest impact. Smaller impact was observed in case of adjustments, whereas the role of statistical discrepancies was minimal. The balance of the impact of particular categories contributed to the fact that SFA was much lower than when single categories were involved.

\section{Public debt in Poland analyzed while taking SFA into consideration}

Poland does not use SFA in the process of assessing the dynamics of public debt. Although Poland reports this category to the European Commission within the procedure of excessive deficit. It is not taken directly into consideration in the process of public debt management. Hence, there appears the question whether SFA brings new information regarding the dynamics of debt. This issue is particularly important because public debt of Poland in the years 2005-2017 got close to the constitutional limit of $60 \%$ GDP. It has been already mentioned in earlier research that the larger are the restrictions connected with fiscal rules, the stronger is politicians' tendency to ignore the restrictions. Additionally, the analysis of the value of SFA for the countries of the European Union (which was presented in the previous subchapter) shows in some cases that SFA in the Union adopts substantial values.

In the analyzed period changes in the values of SFA in Poland remained under strong impact of the value of public debt. However, it does not change considerably, which results from the fact that already in 2006 the level of debt amounted to $47.3 \%$ GDP and it got close to the first prudential measure (50\% GDP 3 ). The subsequent two years brought the acceleration of GDP increase, thanks to which public debt increased at slower rate, whereas its relation to GDP decreased. The worsening of the economic situation contributed to the fact that in 2010 the first prudential measure has been crossed, whereas the debt level reached 51,7\% GDP. After two next years it amounted to $53,3 \%$ GDP, which makes it close to the second prudential measure that causes considerably more serious restrictions in the fiscal policy. Additionally, since 2009 budget deficit has been higher than 3\% GDP mentioned in the Maastricht Treaty. The consequence was the activation of the Excessive Deficit Procedure (EDP) towards Poland. Therefore, the subsequent governments had to undertake activities preventing the crossing of prudential measures and leading to the improvement of situation in terms of the budget deficit. Owing to the unpopular character of the reforms leading to stable improvement of the situation in state budget, there were undertaken mainly activities leading to the ignorance of limitations. The most extreme case was the denomination of bonds being the possession of OFE and also substantial reduction of resources and the importance of the second pension tier (in 2014). However, the reduction of debt level was

3 The measure has already been removed. 
temporary and in subsequent years the debt began to increase despite the fact that deficits decreased owing to the improvement of the economic situation.

Stock-flow adjustment in Poland in the years 2005-2017was characterized by considerable changeability, which was presented in chart 4. In the years 2006, 2008, 2011, 2015 and 2016 the value of SFA was positive, which means that debt increased to a larger degree than the budget deficit would imply. Within three years the value of SFA reached as much as approx. $2 \%$ GDP. What is particularly alarming is significant increase between 2014 and 2016. In the subsequent years (with the exception of 2007) SFA was negative, i.e. debt increased less than the value of the deficit. There were also years when the difference reached $2 \%$. The specific year was 2014 when there was observed denomination of bonds from the system of open pension funds. However, this case was not assessed positively because it means the resignation from the formation of the fully funded pillar in Polish pension system. Thus the changes are rather substantial, which is caused by such factors as the changes of exchange rates in Poland and the usage of operations involving financial assets in order to reduce the debt level. One may observe in chart 4 that budget deficit was not correlated with the value of the budget deficit. When the deficit reached the maximum level of more than 7\% GDP (the years 2009-2010), SFA remained at low level. However, the reduction of deficit is accompanied by the irregular fluctuations of SFA.

CHART 4

\section{SFA and the deficit of general government sector in Poland in the years 2005-2017 (in \% GDP)}

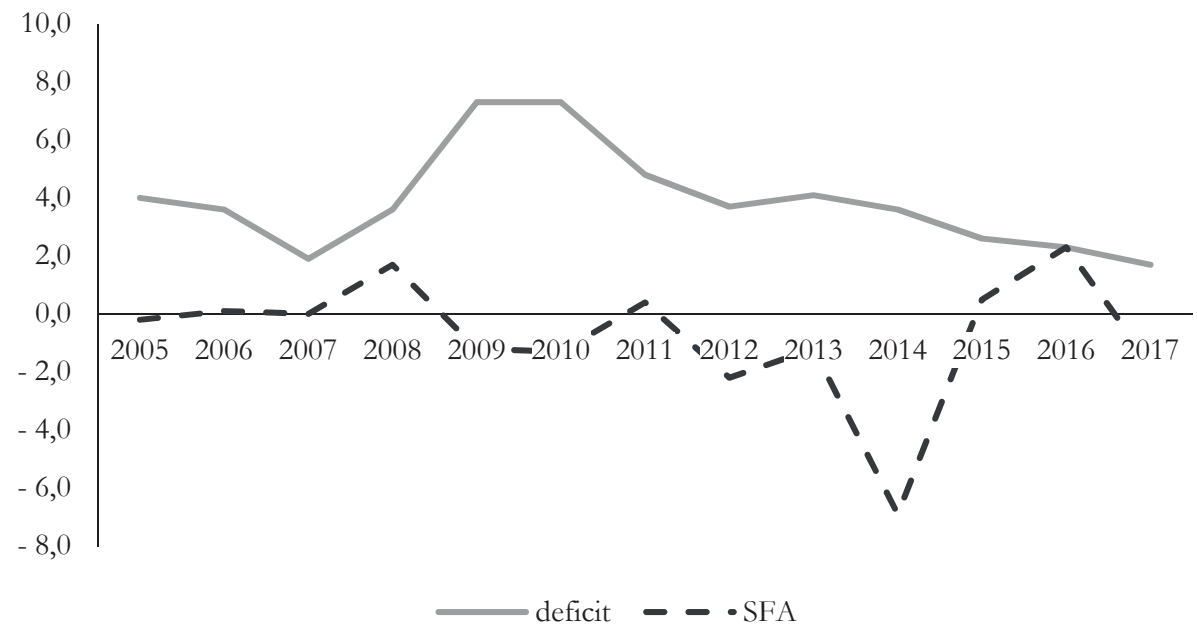

Source: own elaboration on the basis of data obtained from the following reports: [Stock-flow adjustment (SFA) for the Member States..., 2006-2018]. 
The structure of SFA in Poland presented in chart 5 differs from the analysis for Union European countries. In Poland the role of particular components is more unstable. In 2014 focus is paid especially to the category of adjustments caused by the remitting of bonds being the possession of OFE. However, this event happened only once and it is impossible to repeat it on a regular basis. In the years 2005-2017 the value of adjustments was two times more negative than positive. The analysis of the average value of adjustments shows that the negative values considerably more decreased the debt than the positive values increased it. The net acquisition of assets was five times negative, while once it amounted to 0 . The average of positive values was higher than the average of negative values. Hence financial operations had larger impact on the increase of debt than adjustments. However, there was not such significant value as in case of adjustments. Third part of SFA - statistical discrepancies - had slight impact on the debt level but the impact had two-way character. Their maximum value amounted to $\pm 0.2 \%$ GDP, which (in comparison with other categories) is an insignificant value. To conclude, the structure of Polish SFA is subject to major fluctuations. In the years 2012-2016 one may point at the tendency where all the categories go towards positive and increasing values, but owing to the improvement of economic situation in 2017 there occurred reversal of this tendency.

CHART 5

The structure of SFA for Poland in the years 2013-2016 (in \% GDP)

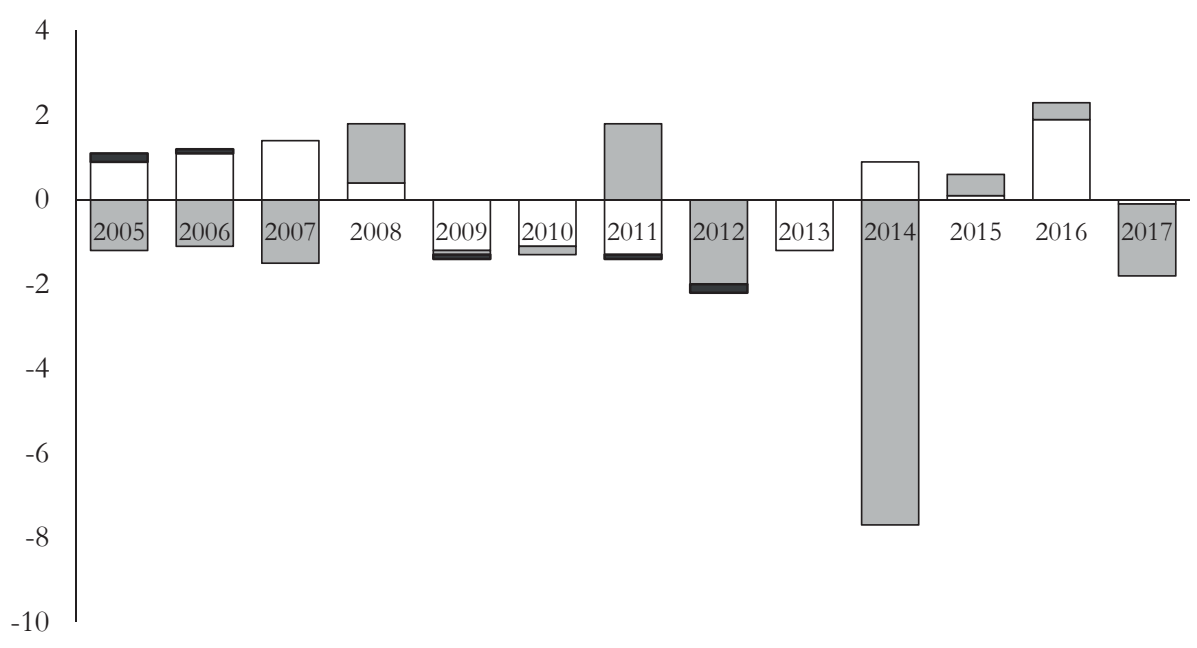

$\square$ Net acquisition of financial assets $\square$ Adjustments $\square$ Statistical discrepancies

Source: own elaboration on the basis of data obtained from the following reports: [Stock-flow adjustment (SFA) for the Member States..., 2006-2018]. 
To sum up, in the years 2005-2017 the value of SFA in Poland was very unstable, but in recent years it has been particularly essential for the values of debt increase since it reached values higher than $\pm 2 \%$ GDP (once it reached the level of $-6.9 \%$ GDP). Both the acquisition of net financial assets and the adjustments were subject to major fluctuations, but they affected debt in opposite ways. The influence of statistical discrepancies was insignificant and it did not result in major changes in the level of public debt.

\section{Conclusions}

The conducted analysis enables drawing the conclusion that stock-flow adjustment is an essential element of assessing debt dynamics. Both in countries of the European Union and in Poland SFA results in changes in the level of public debt to a rather large degree in comparison with the limits for the level of budget deficit specified in the Maastricht Treaty. In some years it achieves the values higher than $\pm 10 \%$ GDP, whereas the level higher than $\pm 5 \%$ GDP occurs relatively often. The European Union actively employs this category for the assessment of fiscal stability of member states connected with the procedure of excessive deficit. In Poland this indicator is not used by the government in the process of public debt management. It appears to be comprehensible since SFA reflects the circumvention of fiscal rules and activities related to creative accounting, while governments are not interested in the transparency of such operations. Therefore, it is essential to use SFA in the extraneous process of assessing fiscal policy and public debt management and point at possible irregularities.

\section{References}

Abbas S.M.A., Belhocine N., El-Ganainy A., Horton M., 2011, Historical Patterns and Dynamics of Public Debt - Evidence From a New Database, "IMF Economic Review", vol. 59 , no. 4.

Buti M., Nogueira Martins J., Turrini A., 2007, From Deficit to Debt and Back: Political Incentives under Numerical Fical Rules, "CESifo Economic Studies", vol. 53, DOI: 10.1093/cesifo/ifm003.

Cafiso C., Cellini R., 2014, Fiscal consolidation and public debt in Europe, "International Tax Public Finance", vol. 21, p. 614-644, DOI: 10.1007/s10797-014-9319-y.

Chojna-Duch E., 2007, Polskie prawo finansowe. Finanse publiczne, Lexis-Nexis, Warszawa. European Commission, 2017, Vade Mecum on the Stability and Growth Pact, Publications Office of the European Union, Luxembourg.

Hagen J. von, Wolf G.B., 2004, What do deficits tell us about debt? Emirical evidence on creative accounting with fiscal rules in the EU?, "Deutsche Bundesbank Discussion Paper", series 1: Studies of the Economic Research Centre, no. 38. 
Hagen J. von., Wolf G.B., 2006, What do deficits tell us about debt? Empirical evidence on creative accounting with fiscal rules in the EU, "Journal of Banking \& Finances", vol. 30, DOI: 10.1016/j.jbankfin.2006.05.011.

Jarmilo L., Mullas-Granados C., Kimani E., 2017, Debt spikes and stock-flow adjustment: Emerging economies perspective, "Journal of Economics and Business", vol. 94.

Maltritz D., Würste S., 2015, Determinants of budget deficits in Europe: The role and relations of fiscal rules, fiscal councils, creative accounting and the Euro, "Economic Modelling", vol. 48.

Maltritz D., Wüste S., 2015, Determinanst of budget deficits in Europe: The role and relations of fiscal rules, fiscal council, creative accounting and the Euro, "Economic Modelling", vol. 48, DOI: 10.1016/j.econmod.2014.12.001.

Raporty rocżne Dlug publiczny z lat 2005-2016, 2017, Ministerstwo Finansów, Warszawa.

Regulation (EU) no. 1173/2011 of the European Parliament and of the Council of 16 November 2011 on the effective enforcement of budgetary surveillance in the euro area, Official Journal of the European Union 306/1 of 23.11.2011.

Regulation (EU) no. 1174/2011 of the European Parliament and of the Council of 16 November 2011 on enforcement measures to correct excessive measures macroeconomic imbalances in the euro area, Official Journal of the European Union $306 / 8$ of 23.11 .2011$.

Regulation (EU) no. 1175/2011 of 16 November 2011 amending Council Regulation (EC) no. 1466/97 on the strengthening of the surveillance of budgetary positions and the surveillance and coordination of economic policies, Official Journal of the European Union 306/12 of 23.11.2011.

Regulation (EU) no. 1176/2011 of the European Parliament and of the Council of 16 November 2011 on the prevention and correction of macroeconomic imbalances, Official Journal of the European Union 306/25 of 23.11.2011.

Regulation (EU) no. 1177/2011 of 8 November 2011 amending Regulation (EC) No $1467 / 97$ on speeding up and clarifying the implementation of the excessive deficit procedure, Official Journal of the European Union of 23.11.2011.

Regulation (EU) no. 472/2013 of 21 May 2013 on the strengthening of economic and budgetary surveillance of Member States in the euro area experiencing or threatened with serious difficulties with respect to their financial stability, Official Journal of the European Union 140 of 27.05.2013.

Regulation (EU) no. 473/2013 of 21 May 2013 on common provisions for monitoring and assessing draft budgetary plans and ensuring the correction of excessive deficit of the Member States in the euro area, Official Journal of the European Union 140/11 of 27.05.2013.

Reischmann M., 2016, Creative accounting and electoral motives: Evidence from OECD countries, "Journal of Comparative Economics", vol. 44.

Rybacek V., 2015, How to stabilize debt while running deficit, "Statistika", vol. 95(3).

Samuelson P.A., Nordhaus W.D., 2000, Ekonomia, vol. 2, Wydawnictwo Naukowe PWN, Warszawa.

Stock-flow adjustment (SFA) for the Member States, the euro area and the EU28 for the years 2005-2018, Eurostat, http://ec.europa.eu/eurostat [date of entry: 30.01.2018]. 
Strategie zarzadzania dtugiem sektora finansón publicznych ₹ lat 2005-2017, The Ministry of Finance, Warszawa.

Traktat o funkcionowaniu Unii Europejskiej, Dz. UE C/326/47, 26.10.2012.

Trzcińska A., 2013, Europejski Mechaniżm Stabilności jako stabilizator w planowanej unii finansowej, https://www.nbp.pl/badania/seminaria/10iv2013.pdf [date of entry: 15.05.2018].

Wernik A., 2011, Problemy definicji dtugu publicznego, „Studia BAS”, no. 4(28). 